\title{
URBAN RECREATIONAL PARKS TO OFFSET THE FLOODING OF RIVERS: LA DEVESA OF GIRONA -CATALONIA- (19TH CENTURY)
}

\author{
Ramon RIPOLL ${ }^{1}$, Jordi GOMIS ${ }^{2}$ (D), Carlos TURÓN ${ }^{3}$, Miquel-Àngel CHAMORRO $^{4}$
}

\author{
DOI: 10.21163/GT_2020.151.03
}

\begin{abstract}
:
In the 18th and 19th centuries, hydraulic works played an important role in economic development throughout Europe. There has been much research into the construction of dikes, canals and bridges to protect against, harness, and control the unbridled power of rivers; but there is still a lack of insight into how these functional, productive and social goals combined for purely cultural purposes. The hydraulic engineering work that is the Devesa urban park of Girona (located near the confluence of the Ter, Onyar and Güell rivers) is a magnificent example that fuses territorial engineering and urban architecture. Its design involves 18th and 19th century solutions to resolve the continuous flooding of the city of Girona, combining perfectly with its citizens' social, cultural and recreational activities.
\end{abstract}

Key-words: Hydraulic Geography, Urban Geography, Civil Engineering, City Planning.

\section{INTRODUCTION}

The aim is to study the relationship between urban geography and the geography of rivers. There are historical examples of how harmonization between nature and construction is achieved by culturizing hydraulic engineering. The analysis of the city of Girona provides us with prolific documentation on such blended solutions. In this case, the construction during the second half of the 19th century of a large park at the confluence of four rivers enabled largely solving the urban destruction caused by river flooding. The work methodology used is based on the graphic study of surveying and a historical study of documents on the Devesa park. The research requires reviewing the works that cast doubt on both the technological training of academic architects and the humanistic view of engineers and of many master builders. The findings reveal that technology and humanism can complement each other perfectly. The documentary sources used are the Girona Municipal Archives, the Girona Historical Archive and the Archive of the Crown of Aragon.

Let us recall that many pre-industrial European cities are located near rivers. They are riverine settlements that take advantage of direct access to water for residential, manufacturing, agricultural, etc. purposes (Sambrico, 1990). Yet, many of them suffer from flooding, especially if they have been built unwisely in areas prone to flooding by rivers whose flow is irregular. In this case, river courses pose a constant threat of destruction and

\footnotetext{
${ }^{1,4}$ Universitat de Girona, 61 Maria Aurèlia Capmany Street, 17003-Girona, Spain, ramon.ripoll@udg.edu,mangel.chamorro@udg.edu

${ }^{2,3}$ Universitat Rovira i Virgili, 26 Països Catalans Avenue, 43007-Tarragona, Spain, jordi.gomis@urv.cat,carlos.turon@urv.cat
} 
calamity. One such example is the city of Girona. During the late Medieval and modern periods, the city irresponsibly urbanized easily flooded areas implementing medieval and modern defensive walls as the only means of protection (AHM, 1820). The hydraulic situation was very serious because these historic settlements were located on both sides of two rivers -the Onyar and the Galligans- creating a major urban clamp strangling the hydraulic section, and at the same time on the banks of the confluence of the rivers Güell and Ter, creating the corresponding dam effect on the city (Ribas, 2006). Such organization was highly favourable and optimal in times of plenty and rather unfavourable and dramatic in periods of torrential rain (Table 1).

Table 1.

\section{FLOODS 1716-1970}

\begin{tabular}{|c|c|c|c|}
\hline & Year & Rivers & \\
\hline 1 & 1716 & Onyar and Ter & 2 \\
\hline 2 & 1726 & Onyar and Ter & 2 \\
\hline 3 & 1732 & Galligans and Onyar & 2 \\
\hline 4 & 1735 & Galligans & 1 \\
\hline 5 & 1736 & Galligans, Onyar and Ter & 3 \\
\hline 6 & 1738 & Galligans & 1 \\
\hline 7 & 1740 & Onyar and Ter & 2 \\
\hline 8 & 1741 & Ter & 1 \\
\hline 9 & 1742 & Ter & 1 \\
\hline 10 & 1758 & Ter & 1 \\
\hline 11 & 1759 & Galligans and Güell & 2 \\
\hline 12 & 1762 & Ter & 1 \\
\hline 13 & 1763 & Ter & 1 \\
\hline 14 & 1765 & Galligans, Onyar and Ter & 3 \\
\hline 15 & 1765 & Galligans, Onyar and Güell & 3 \\
\hline 16 & 1765 & Onyar & 1 \\
\hline 17 & 1772 & Onyar & 1 \\
\hline 18 & 1776 & Galligans, Onyar, Ter and Güell & 4 \\
\hline 19 & 1777 & Galligans, Onyar and Ter & 3 \\
\hline 20 & 1777 & Galligans, Onyar and Ter & 3 \\
\hline 21 & 1783 & Galligans, Onyar, Ter and Güell & 4 \\
\hline 22 & 1787 & Onyar and Ter & 2 \\
\hline 23 & 1790 & Onyar & 1 \\
\hline 24 & 1791 & Ter & 1 \\
\hline 25 & 1793 & Onyar and Ter & 2 \\
\hline 26 & 1795 & Ter & 1 \\
\hline 27 & 1798 & Ter & 1 \\
\hline 28 & 1801 & Galligans and Onyar & 2 \\
\hline 29 & 1802 & Onyar and Ter & 2 \\
\hline 30 & 1804 & Ter & 1 \\
\hline
\end{tabular}

Floods between 1716 and 1970 (AMG 1716-1970).

\begin{tabular}{|l|l|l|l|}
\multicolumn{5}{|l}{ Year } & 1 \\
\hline 31 & 1814 & Ter & 1 \\
\hline 32 & 1814 & Ter & 1 \\
\hline 33 & 1816 & Ter & 1 \\
\hline 34 & 1819 & Ter & 1 \\
\hline 35 & 1820 & Ter & 2 \\
\hline 36 & 1822 & Onyar and Ter & 2 \\
\hline 37 & 1823 & Ter & 2 \\
\hline 38 & 1826 & Onyar and Ter & 2 \\
\hline 39 & 1826 & Onyar and Ter & 1 \\
\hline 40 & 1827 & Onyar & 4 \\
\hline 41 & 1828 & Galligans, Onyar, Ter and Güell & 4 \\
\hline 42 & 1829 & Onyar, Teri and Güell & 3 \\
\hline 43 & 1829 & Onyar and Güell & 2 \\
\hline 44 & 1831 & Onyar and Ter & 2 \\
\hline 45 & 1832 & Onyar & 1 \\
\hline 46 & 1832 & Onyar & 1 \\
\hline 47 & 1833 & Ter & 1 \\
\hline 48 & 1836 & Ter & 1 \\
\hline 49 & 1838 & Ter & 1 \\
\hline 50 & 1838 & Ter & 1 \\
\hline 51 & 1839 & Onyar and Ter & 2 \\
\hline 52 & 1839 & Onyar and Ter & 2 \\
\hline 53 & 1840 & Onyar & 1 \\
\hline 54 & 1840 & Onyar & 1 \\
\hline 55 & 1843 & Galligans, Onyar, Ter and Güell & 4 \\
\hline 56 & 1850 & Galligans, Onyar, Ter and Güell & 4 \\
\hline 57 & 1853 & Onyar and Ter & 2 \\
\hline 58 & 1861 & Onyar & 1 \\
\hline 59 & 1861 & Galligans, Onyar, Ter and Güell & 4 \\
\hline 60 & 1872 & Onyar and Ter & 2 \\
\hline & & \\
\hline
\end{tabular}

\begin{tabular}{|l|l|l|c|}
\multicolumn{5}{|c}{ Year } \\
\hline 61 & 1876 & Onyar, Ter and Güell & $\mathbf{3}$ \\
\hline 62 & 1882 & Güell & $\mathbf{1}$ \\
\hline 63 & 1884 & Galligans, Onyar and Güell & $\mathbf{3}$ \\
\hline 64 & 1884 & Galligans, Onyar, Ter and Güell & $\mathbf{4}$ \\
\hline 65 & 1885 & Onyar and Ter & $\mathbf{2}$ \\
\hline 66 & 1898 & Galligans, Onyar, Ter and Güell & $\mathbf{4}$ \\
\hline 67 & 1898 & Ter & $\mathbf{1}$ \\
\hline 68 & 1902 & Onyar and Ter & $\mathbf{2}$ \\
\hline 69 & 1903 & Onyar and Ter & $\mathbf{2}$ \\
\hline 70 & 1907 & Onyar & $\mathbf{1}$ \\
\hline 71 & 1908 & Onyar and Ter & $\mathbf{2}$ \\
\hline 72 & 1919 & Ter & $\mathbf{1}$ \\
\hline 73 & 1920 & Onyar and Ter & $\mathbf{2}$ \\
\hline 74 & 1920 & Onyar & $\mathbf{1}$ \\
\hline 75 & 1921 & Ter and Güell & $\mathbf{2}$ \\
\hline 76 & 1926 & Güell & $\mathbf{1}$ \\
\hline 77 & 1932 & Ter & $\mathbf{1}$ \\
\hline 78 & 1939 & Onyar & $\mathbf{1}$ \\
\hline 79 & 1940 & Onyar, Ter and Güell & $\mathbf{3}$ \\
\hline 80 & 1943 & Onyar & $\mathbf{1}$ \\
\hline 81 & 1944 & Onyar and Ter & $\mathbf{2}$ \\
\hline 82 & 1948 & Galligans, Onyar and Ter & $\mathbf{3}$ \\
\hline 83 & 1962 & Onyar, Ter and Güell & $\mathbf{3}$ \\
\hline 84 & 1963 & Onyar, Ter and Güell & $\mathbf{3}$ \\
\hline 85 & 1963 & Onyar & $\mathbf{1}$ \\
\hline 86 & 1965 & Onyar & $\mathbf{1}$ \\
\hline 87 & 1969 & Onyar & $\mathbf{1}$ \\
\hline 88 & 1969 & Onyar & $\mathbf{1}$ \\
\hline 89 & 1970 & Galligans, Onyar, Ter and Güell & $\mathbf{4}$ \\
\hline 90 & 1971 & Onyar, Ter and Güell & $\mathbf{3}$ \\
\hline & \multicolumn{2}{|c}{ TOTAL FLOODS } & $\mathbf{1 6 8}$ \\
\hline
\end{tabular}

The worst floods suffered by the city of Girona took place in 1732 with 11 houses destroyed, in 1763 with the evacuation of residents through the perforated dividing walls, in 1843 with 100 killed and 22 houses destroyed, in 1861 with two dead, one house destroyed and 72 houses severely affected, and so on. Year after year during the period of heavy rains, such destruction affected walls, dikes, embankments, riverbeds, dams, canals and bridges as well as houses, mills, factories, orchards, fields and plantations. Socially speaking, these situations were experienced with tension and drama because the citizens of the most affected neighbourhoods had to leave their homes hurriedly, both by day and at night. 
Evacuations were conducted to the sound of the bells of the city announcing the flood, the lamplighters required double provisions of oil (AHM, 1814), those responsible for the city gates had to open them to allow the water to run freely (AHM, 1814) and, at the same time, churches and convents were called to offer supplications (AHM, 1814).

\section{FLUVIAL REALITY AND TECHNOLOGY}

The extensive documentation provided by Girona City Council manuals meticulously describes the damage caused by floods and the technical, constructive and economic means for their repair. Such information is repeated year after year, throughout the 18th and 19th centuries. The continued destruction surpassed the technical and economic resources of the city and each year the municipal authorities had to deal with an extreme situation to avoid paralysing the urban, productive and regional communications infrastructures. In all these cases a gap and dysfunction were noted between the reality of the river and the constructive means available to definitively solve the problem (Ripoll, 2005).

First, there was a clear lack of economic resources. Hence, the difficulties in seeking and raising funds, implementing and imposing new taxes on the population, funding and finding guarantors, disbursing and paying at the start, during and at the end of the work, etc. were reported. In addition, systems were sought that would allow the greatest possible cost savings, such as making plans and projects with effective solutions, drawing up more detailed job cost sheets on the works to be carried out, awarding the works by public auction to the highest bidder with a closed budget, or awarding the works by direct labour, if such meant lower costs. The economic insecurity is very clearly illustrated by the occasions on which requests were made to reduce the wages of the workers and labourers of the waterworks to one third (AHM, 1787). This lack of financial resources was compounded when the short duration of the effort made could be seen. According to the sources consulted, it was known in advance that the solutions adopted and the financial resources used often did not last long due to regular episodes of torrential rain. This idea of general precariousness is strengthened by the statement by the architect Cusanes on the futility of most of the repairs carried out on the river Ter (AHM, 1790). Nevertheless, among the most optimistic views is the analysis by the engineer Azara when he said that the most enduring means were the planting of trees and the implementation of strong stakes and planks, as they usually last up to a maximum of 50 years (AHM, 1778).

It is also interesting to note that most of the solutions adopted were based solely on technological means, ranging from the simplest to the most complex constructive proposals. The simplest constructive means included: cleaning the rivers, rebuilding the damage caused, strengthening the channels, building breakwaters, closing the new riverbeds opened by the rivers, replanting trees, and so forth. These works required moving sand and earth, driving oak, poplar or elm stakes, nailing oak planks, wedging stones, transporting ashlars or large stones, making dry stone or cobble embankments, etc. It is worth mentioning some reports that speak of the advantages provided by embankments made using river cobbles because they are more resistant to flash flooding than stakes or masonry. In this case, the engineer Boer (AHM, 1778) compared river water to a cannonball that does more damage to a masonry wall than to a dirt wall or sandbags. He also emphasized the importance of protective breakwaters at specific points, such as the royal walk in the district of Pedret (AHM, 1800), etc. The most striking observation is the assiduity of the floods, which brought many hydraulic constructions to a premature end. In these cases, materials and work tools were often carried away by flash floods (AHM, 1820). The technically more complex solutions 
involved diverting the rivers Ter (AHM, 1769), Güell (AHM, 1796) etc. Among these proposals, the most difficult to build were those proposed in 1802, which consisted of returning the Ter to its original course at a cost of 3,463,200 reales, or lowering the bed of the river Ter at a cost of 12,720,000 reales, therefore four times more expensive than the proposal to return the Ter to its original course. The most expensive was to divert the river Ter fully behind the Turó de Roca hill, at a cost of 348,347,364 reales, a hundred times more expensive than returning the Ter to its original course. Other proposals included moving the Güell river away from the city by means of an earth embankment or diverting the Onyar around the city. Many of these studies were unachievable, as were most of the financial means proposed for their implementation: taxes, levies and urban tolls (AHM, 1803).

We should also mention some more realistic studies and analyses that provided affordable solutions to the problem. Such is the case of Girona City Council, when it recognized that cutting down all the trees of the Devesa would leave much of the city unprotected (AHM, 1796), or the orders issued by the commander-in-chief of the engineers forcing the replanting of the trees of the Devesa for this very reason, to protect the city (AHM, 1796). These observations considered the woodland of the Devesa at the confluence of the four rivers as being one of the most important means of protection the city could have against flooding (Aragó, 1980). This conclusion was reached after having cut all the trees of the Devesa to cover the costs of military works to recompose the city walls due to the proximity of the French Army of Occupation (AHM, 1795) (Fig. 1).

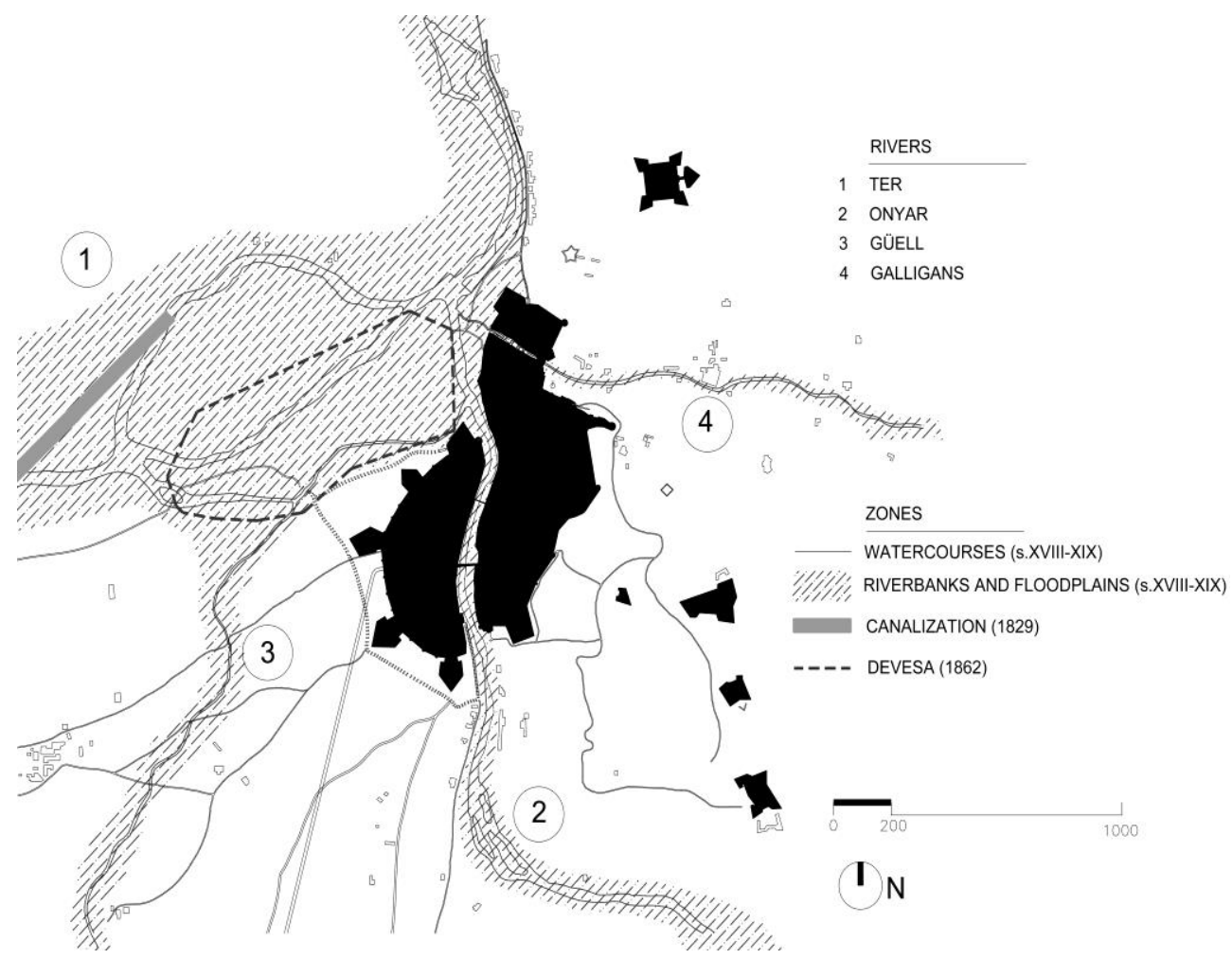

Fig. 1. Evolution of the Devesa park in the 18th and 19th centuries (Drawing by R. Ripoll, private archive, 2018). 


\section{TECHNOLOGY AND URBAN PARK}

The industrial revolution caused profound changes in the cities, especially in factory towns. Population growth and the concentration of large masses of population quickly turned them into "big-towns". However, there were no suitable planning responses to this problem, with purely speculative prevailing in new designs of towns (Gomis \& Turón, 2015). As the 19th century progressed, it began to be seen that the most affordable solution in terms of finance and construction processes largely involved combining, harmonizing and blending technological proposals to improve the Ter river course hydraulic section and social proposals to transform the Devesa into an urban park (Ripoll, 2005). The former aimed to improve the river course section and the latter to stabilize the soil. For the first time, complementarity between river technology, moving the Ter river away from the city, and the architecture of the landscape, building a large urban park, were entertained (Fig. 2).

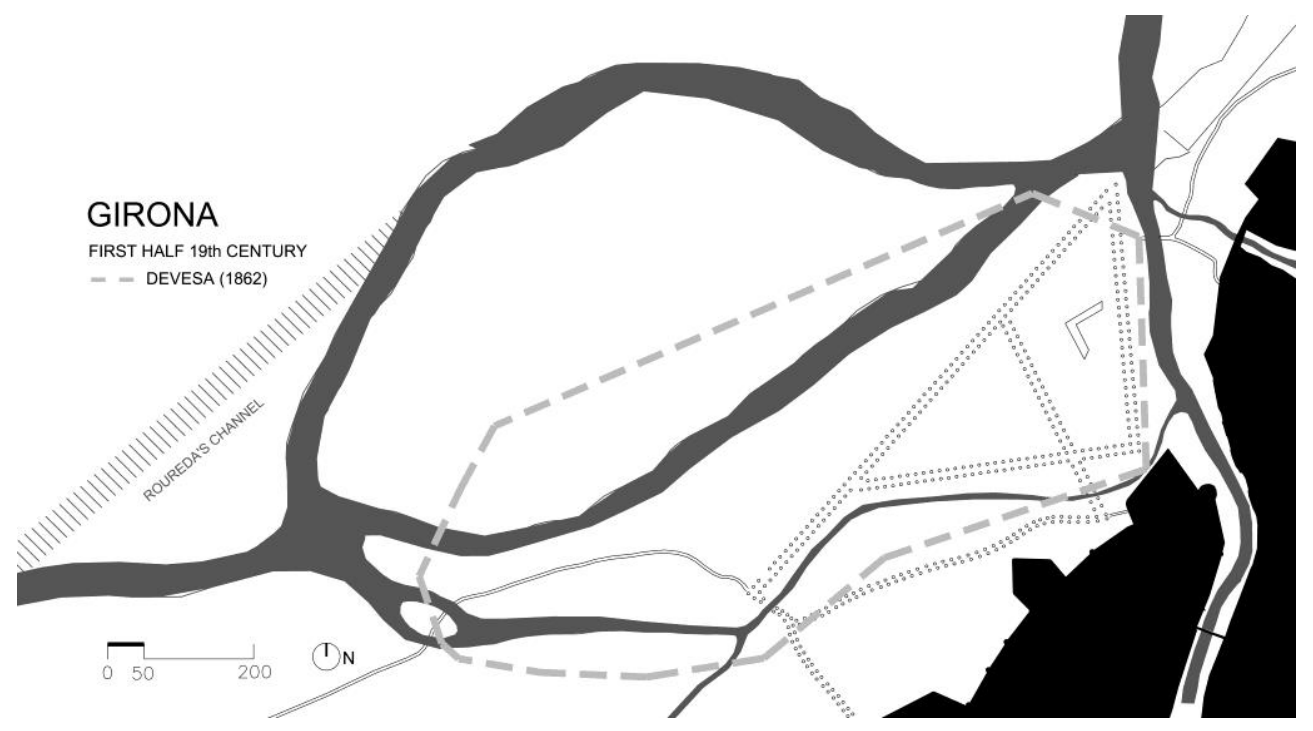

Fig. 2. Devesa Park at the start of the 19th century (Drawing by R. Ripoll, private archive, 2018).

The first aspect of this new approach began in 1826, when there was a project to move the Ter river back to its original course. This involved the construction of an $856 \mathrm{~m}$-long, $1.6 \mathrm{~m}$ deep channel, called the Roureda, and of an embankment, or dam, to direct the river water to the new channel. The project was led by the expert master builders Miguel Fàbrega and Benito Santigosa with a budget of 4,210,740 reales. This amount could be interpreted as relatively tight as it represented $20 \%$ more than the budget of a similar project carried out 24 years earlier, in 1802. The aim was to again move the river away from the city and the farmland of the Girona plain (AHM, 1826). Following the refusal by the king (AHM, 1827) to help financially with funds raised by the land registry (AHM, 1826), local and municipal authorities struggled to find the financial resources to carry out the works (AHM, 1827). In this case, the construction of the works of the Roureda canal and the planting of trees to consolidate the works to construct the canal started to be combined (AHM, 1829). The works were directed by the geometrician Luis Barnoya and the architect José Cabot. 
As of 1830, works began to drain, fill in, normalize and consolidate the areas freed by the new course of the Ter. Actions also began to find more compatible functions for this new fluvial land. For example, there was an initiative to purge the area of agricultural uses by tenants farming the land (AHM, 1837). Years later this same operation was repeated to put an end to using the land for grazing animals (AHM, 1865). In parallel, there was increased tree planting (AHM, 1850). According to reports, the result, in the second half of the 19th century, was the existence of slender, lush plantains measuring $1.5 \mathrm{~m}$ in circumference with a $5 \mathrm{~m}$ branchless trunk standing between 15 and 20 metres high. These reports also describe how the trees were arranged in a grid $22.5 \mathrm{~m}$ apart. They also describe the existence of a nursery of plantains (AHM, 1882).

Thus, in the second half of the 19th century, the Devesa described in these reports was very similar to what we find today and followed the characteristics of the Devesa urban park as proposed by the architect Martí Sureda in 1862, a project for an urban park covering a surface area of $388,377 \mathrm{~m} 2$ which accounted for $82 \%$ of the surface area of the entire city of Girona at the time $(459,757 \mathrm{~m} 2)$ and consisted of six large squares of gardens, measuring between 8,340 $\mathrm{m} 2$ and 10,912 $\mathrm{m} 2$ each, bounded by avenues of large trees (Fig. 3). We should also mention the Field of Mars, or a rectangular open space of 63,842 m2. Finally, the entire assembly is flanked on three sides by irregularly-shaped neighbouring gardens located in the north, west and south covering 14,966 $\mathrm{m} 2,55,115 \mathrm{~m} 2$ and 49,949 $\mathrm{m} 2$ respectively (Ferrer, 1994).

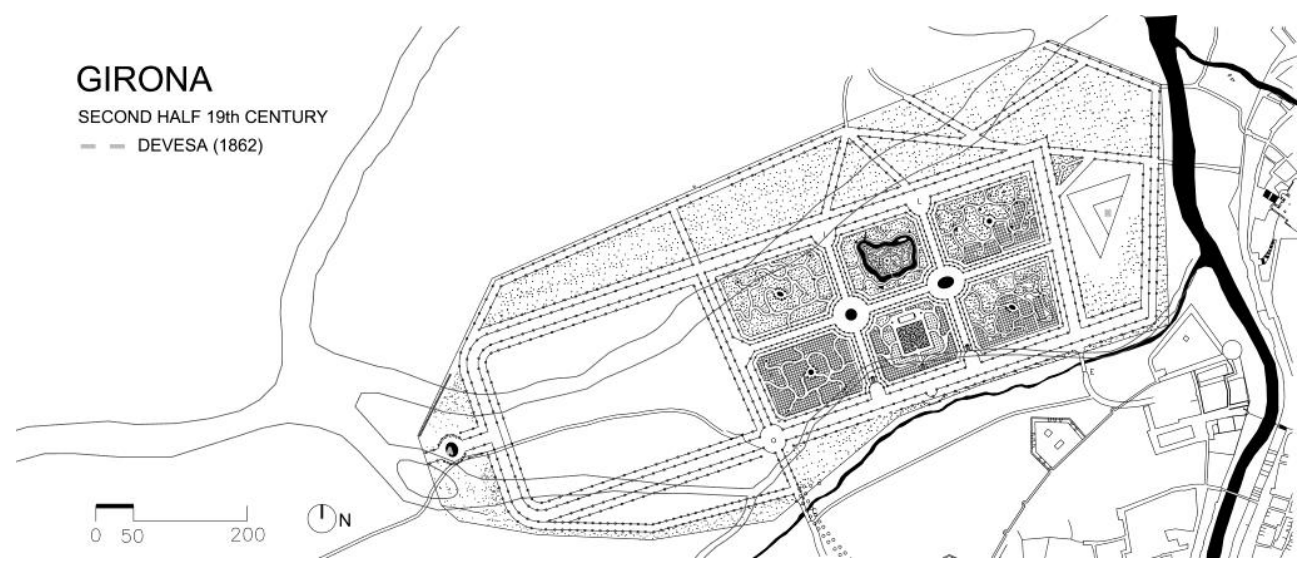

Fig. 3. The project for the Devesa park by Martí Sureda, 1862

(Drawing by R. Ripoll, private archive, 2018).

The park designed by Sureda was in keeping with the design of French gardens, perfectly combining the overall composition of totally geometrical longitudinal and transversal avenues. The alignments defined closed inner spaces with pleasure gardens containing erratic walkways. Each of these spaces had its corresponding centres of interest formed by ponds, canals, musicians' platforms, or even the odd pergola (Desimini \& Waldheim, 2016). Similarly, Martí Sureda's project defined a maze made of perfectly geometrical tree-lined walls symbolizing the certainty and disorientation of life. The maze has four entrances, three of which are intertwined (Fig. 4). 


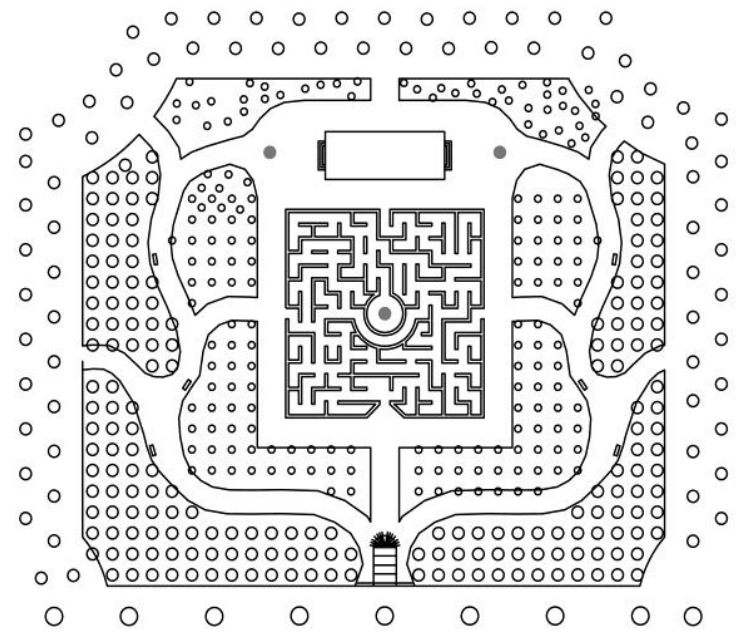

DEVESA'S MAZE

MARTI SUREDA (1862)
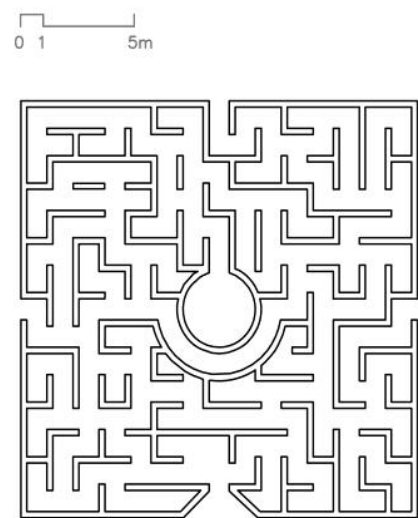

Fig. 4. Detail of the project for the urban park by Martí Sureda, 1862

(Drawing by R. Ripoll, private archive, 2018).

It should be highlighted that the Devesa urban park has lasted until today preserving most of the general characteristics described in Martí Sureda's project of 1862. Only four of the six inner gardens and a few specific complementary elements have not been implemented. During the last century and a half, the Devesa park has not only played the role of allaying the most dramatic dangers of flooding on the city of Girona, but also of partially urbanizing the Ter river as it passes through the city. In this case, the Devesa urban park has helped update river-related vocabulary in the city of Girona. For example the expressions found in historical documents prior to 1862 such as banks, warpage, bed, pasture, field or grove have been replaced successively by such contemporary expressions after 1862 as recreational, social relations, stroll and urban park.

\section{CONCLUSIONS}

The example studied is paradigmatic in two ways. First, the intention to put sophisticated leisure gardens that were reserved in Europe for the nobility, such as the royal gardens of the palace of Drottningholm (Stockholm, 1811), the oldest in the world in use, at the service of all citizens of a secondary population of southern Europe in 1862.

And secondly, already during the second half of the 19th century, it anticipated the unlimited complementarity between technology and architecture, a dual feature that allows building a luxurious, perfect park on the most counterproductive, deteriorated and punished land. 


\section{REFERENCES}

ACA: Archive of the Crown of Aragón.

AHG: Girona Historical Archive.

AHM: Girona Municipal Historical Archive.

Aragó, N. (1980). La Devesa paradís perdut. Girona: COAC.

Desimini, J. \& Waldheim, C. (2016). Cartographic Grounds: Projecting the Landscape Imaginary. New York NY: Princeton Architectural Press.

Ferrer, M. (1998). Martí Sureda Deulovol (1822-1890). Girona. COAC.

Gomis, J. \& Turón C. (2015). Conceptual and instrumental influences in the graphic representation of urbban planning: The industrial Revolution and the 19tk Century. Geographia Technica, 10 (1), pp 44-50.

Ribas, A. (2006). Les inundacions de Girona. Girona: Girona City Council.

Ripoll, R. (2005). L'arquitecte, l'arquitectura i la ciutat. Girona 1760-1835. Barcelona: Publications of Montserrat Abbey.

Sambrico, C. (1990). El "Límite" de la ciudad ilustrada: La ordenación de un espacio urbano. ARQUITECTURA (Revista del Colegio Oficial de Arquitectos de Madrid). Issue SeptemberDecember 1990, No. 286-287 pp. 168-183. 